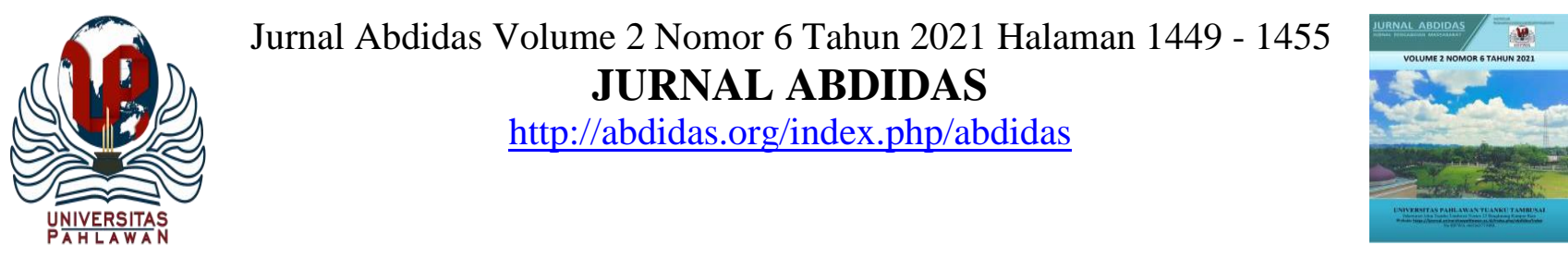

\title{
Peningkatan Hard Skills dan Soft Skills pada Lingkup Organisasi
}

Arsyad Sumantika $^{1 凶}$, Elva Susanti $^{2}$

Teknik Industri, Universitas Putera Batam, Indonesia ${ }^{1,2}$

Email : arsyad.sumantika@ puterabatam.ac.id ${ }^{1}$, elva.susanti@ puterabatam.ac.id ${ }^{2}$

\begin{abstract}
Abstrak
Salah satu kekurangan yang ada di generasi muda saat ini adalah rendahnya keterampilan dalam hal hard skill dan soft skill. Banyaknya pengangguran di Indonesia disebabkan adanya rendahnya keterampilan dan keahlian yang dimiliki. Oleh karena itu diperlukan adanya kemampuan yang mumpuni untuk dapat bersaing. Berdasarkan fenomena tersebut, agar dapat memecahkan masalah yang ada, maka tim pengabdi memfasilitasi permasalahan tersebut dengan mengadakan kegiatan pelatihan hard skill dan soft skill. Metode kegiatan tersebut berupa pelatihan yang dilakukan secara luring dengan target mahasiswa dan generasi muda. Bentuk kegiatan pelatihan tersebut antara lain meliputi pelatihan kepemimpinan, jurnalistik, desain grafis, dan public speaking. Tujuan pelatihan tersebut adalah memberikan bekal berupa keterampilan kepada mahasiswa dan generasi muda dalam menghadapi tingkat pesaingan global yang semakin ketat. Berdasarkan pelaksanaan kegiatan, hasil yang didapatkan adalah peserta menyatakan puas terhadap bentuk pelatihan karena mendapatkan tambahan keterampilan yang berguna untuk bekal di masa depan. Sedangkan kesimpulan yang didapat adalah adanya pelatihan tersebut dapat meningkatkan keterampilan, kepercayaan diri, dan produktivitas kerja para peserta.
\end{abstract}

Kata kunci : generasi muda, hard skill, soft skill

\section{Abstract}

One of the shortcomings that exist in today's young generation is the lack of skills in terms of hard skills and soft skills. The number of unemployed in Indonesia is due to the low skills and expertise possessed. Therefore, it is necessary to have skills that are able to compete. Based on this phenomenon, in order to solve existing problems, the service team facilitates these problems by holding hard skills and soft skills training activities. The method of this activity is in the form of training carried out offline with the target of students and the younger generation. The forms of training activities include leadership training, journalism, graphic design, and public speaking. The purpose of the training is to provide students and young people with skills in the face of increasingly fierce global competition. Based on the implementation of the activities, the results obtained were that participants expressed satisfaction with the form of training because they received additional skills that were useful for future provision. Meanwhile, the conclusion obtained is that the training can improve the skills, confidence, and work productivity of the participants.

Keywords : young generation, hard skills, soft skills

Copyright (c) 2021 Arsyad Sumantika, Elva Susanti

$\triangle$ Corresponding author

Address : Universitas Putera Batam

ISSN 2721-9224 (Media Cetak)

Email : arsyad.sumantika@ puterabatam.ac.id

ISSN 2721- 9216 (Media Online)

DOI : https://doi.org/10.31004/abdidas.v2i6.507 


\section{PENDAHULUAN}

Salah satu tantangan yang dihadapi pada era globalisasi adalah peningkatan kemampuan. Jika mengacu pada kondisi saat ini di era pandemi Covid-19, peningkatan skill atau keterampilan menjadi hal yang mutlak dilakukan oleh setiap orang. Berdasarkan data kajian dari Smeru Research Institute menunjukkan bahwa tingkat pengangguran pada usia mudia di Indonesia relatif tinggi. Jika diuraikan lebih lanjut presentase tingkat penganggur yang berusia muda di Indonesia masih lebih banyak daripada jumlah penganggur muda di dunia. Presentase tingkat pengangguran angkatan muda di Indonesia dari tahun 2015 sampai 2020 berutut-turut adalah 22,6 $\%, 19,5 \%, 20,4 \%, 19,7 \%, 18, .6 \%$, dan naik pada tahun 2020 sebesar 20,5\%. Dibandingkan dengan presentase tingkat pengangguran angkatan muda di dunia pada tahun 2015 sampai 2020 berturut-turut adalah $13,6 \%, 13,8 \%, 13,7 \%, 13,5 \%, 13,6 \%$, dan $13,7 \%$ pada tahun 2020. Hal tersebut berarti bahwa 1 dari 5 orang pada angkatan kerja muda di Indonesia menganggur terutama pada tahun 2020 (Smeru Research Institute, 2020).

Fenomena tersebut menggambarkan bahwa masih banyaknya pengangguran yang terjadi pada tenaga kerja terutama di angkatan muda di Indonesia. Salah satu faktor penyebabnya adalah masih rendahnya skill atau keahlian yang dimiliki oleh tenaga kerja angkatan muda tersebut. Ketika memasuki jenjang perkuliahan masih banyak mahasiswa atau angkatan muda tersebut yang hanya dibekali teori tapi tanpa adanya peningkatan skill atau keahlian yang dapat menjadi nilai lebih bagi individu tersebut.
Dalam kehidupan nyata antara teori yang dipelajari di tingkat Universitas dengan kenyataan di lapangan kadang tidak sejalan, masih banyak berkembang paradigma setelah lulus kuliah langsung mendapatkan pekerjaan atau bahkan membuka pekerjaan merupakan sesuatu hal yang mudah dilakukan oleh setiap orang kecuali individu tersebut memiliki keahlian atau skill yang dapat ditawarkan. Skill atau keahlian merupakan kemampuan teknis yang harus dimiliki oleh calon pekerja seperti kemampuan menggunakan suatu alat atau mesin, mengolah data, melakukan operasi komputer, software, atau hardware, dan mengetahui suatu pengetahuan tertentu yang bermanfaat (Manara, 2014).

Skill atau disebut sebagai kompetensi pekerja merupakan kemampuan yang harus dimiliki oleh setiap individu yang meliputi kemampuan dalam hal keterampilan, pengetahuan, dan sikap kerja. Dalam hal ini kompetensi kerja terdiri dari hard skill dan softskill. Hard skill berkaitan dengan kemampuan dalam aspek kognitif dan keahlian khusus berdasarkan disiplin ilmu tertentu, sedangkan definisi soft skill merupakan perilaku interpersonal yang dibutuhkan dalam upaya pengembangan dan pengoptimalkan kinerja. Oleh karena itu dengan meningkatkan hard skill dan soft skill memberi peluang lebih besar pada individu yang bersangkutan dalam mengembangkan ilmu dan pengetahuannya yang berujung pada tingkat keberhasilan dan kesuksesan di masa depan (Lie \& Darmasetiawan, 2017).

Setiap individu di Indonesia dinyatakan memiliki kesiapan kerja jika individu tersebut menguasai beberapa keterampilan dan pengetahuan yang diperlukan berdasarkan 
persyaratan kerja dipersyaratkan. Untuk mempersiapkan tersebut tidak hanya melakukan peningkatan dalam hal keterampilan kerja saja, namun kepribadian yang baik, pemahaman berpikir, dan mentalitas yang baik diperlukan dalam mendukung kompetensi kerja (Nur Agusta, 2014).

Berdasarkan fenomena tersebut dalam meningkatkan daya saing terutama pada generasi angkatan muda di Indonesia perlu adanya progam peningkatan skill yang berkesinambungan. Salah satu bentuk progam peningkatan skill yang dilakukan oleh tim pengabdian kepata masyarakat adalah meliputi pelatihan kepemimpinan dalam organisasi, kemampuan dalam mengoperasikan software seperti desain grafis, pelatihan public speaking seperti Master of Ceremony (MC), pelatihan jurnalistik, dan lain sebagainya.

Output pelatihan kepemimpinan dalam organisasi adalah membangun setiap individu agar memiliki kepercayaan diri dalam menyampaikan ide atau gagasan, memberikan pengaruh yang baik dan memotivasi kepada orang lain sesuai dengan tujuan bersama yang telah ditetapkan di suatu lingkup organisasi (Solikin et al., 2014). Kemudian pelatihan Master of Ceremony (MC) memiliki tujuan agar mahasiswa dapat menjadi pembawa acara yang handal dalam mengatur jalannya acara pada suatu kegiatan, komunikator yang baik, dan dapat sebagai penentu kelancaran rangkaian suatu acara atau kegiatan. (Hafizah, 2019), sedangkan pelatihan desain grafis ditujukan agar mahasiswa memiliki keterampilan dalam menyampaikan informasi melalui bahasa komunikasi visual yang mudah dimengerti, dipahami, dan bersifat menarik (Dewojati, 2015).
Oleh karena itu dengan melakukan progam peningkatan skill, maka harapannya dapat memberikan kontribusi terhadap kesiapan terutama pada angakatan kerja usia muda untuk menghadapi persaingan global. Skill tidak hanya dipandang sebagai peningkatan kemampuan atau keahlian pada individu yang bersangkutan namun dapat menunjukkan mental, kepribadian, dan watak individu yang kuat.

\section{METODE}

Metode pelaksanaan kegiatan adalah pelatihan hard skill dan soft skill yang dilakukan secara luring. Adapun bentuk kegiatannya meliputi pelatihan pelatihan kepemimipinan, pelatihan Master of Ceremony (MC), desain grafis, dan jurnalistik. Pelaksanaan kegiatan tersebut dilakukan selama 4 hari dari tanggal 22 November - 25 November 2021 bertempat di kota Batam dengan target sasaran peserta adalah mahasiswa atau yang termasuk ke dalam angkatan muda kerja Indonesia.

Palaksanaan kegiatan pada hari pertama mencakup kegiatan dasar pelatihan kepemimpinan dan organisasi, kemudian pada hari kedua mencakup pelatihan Master of Ceremony (MC), pada hari ketiga bentuk kegiatan adalah pelatihan desain grafis, sedangkan pada hari keempat bentuk kegiatann berupa pelatihan jurnalistik.

Adapun pelaksanaan kegiatan pengabdian dalam bentuk pelatihan ini bertujuan untuk meningkatkan kompetensi dan keahlian diluar keilmuan yang mereka miliki sehingga dapat dijadikan sebagai bekal yang berguna pada pada masa yang akan datang. Hal ini berkaitan dengan tingkat persaingan dunia industri yang semakin 
ketat, sehingga membutuhkan sumber daya manusia yang tidak hanya memiliki keilmuan yang didapatkan dari Universitas, tetapi juga memiliki hard skill dan soft skill yang mumpuni.

\section{HASIL DAN PEMBAHASAN}

Kegiatan pengabdian meliputi 4 kegiatan pelatihan, yakni pelatihan kepemimpinan, pelatihan Master of Ceremony (MC), desain grafis, dan jurnalistik. Selama pelatihan tim pengabdi memberikan edukasi mengenai pengembangan diri melalui peningkatan hard skill dan soft skill. Sasaran kegiatan tersebut adalah mahasiswa dan angkatan kerja muda yang berdomisili di Batam. Pada setiap kegiatan juga dilakukan evaluasi apakah dari pelatihan yang dilakukan memberikan manfaat yang signifikan atau justru sebaliknya.

Pada saat pelaksanaan kegiatan, para peserta memiliki semangat dan ketertarikan yang tinggi dalam mengikuti setiap rangkaian acara kegiatan, hal ini dibuktikan adanya beberapa peserta yang proaktif dalam bertanya, menyampaikan ide, dan gagasan selama kegiatan. Beberapa bentuk kemeriahan pelaksanaan kegiatan tersebut dapat dilihat pada gambar 1 mengenai peserta kegiatan pelatihan, gambar 2 mengenai sharing materi kegiatan oleh narasumber.

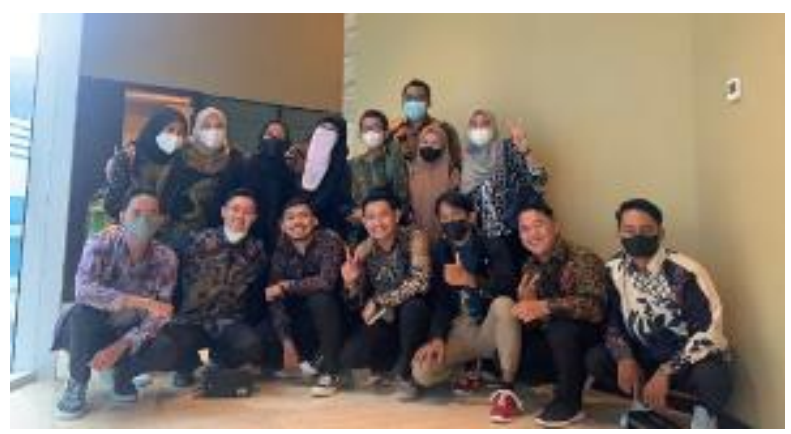

Gambar 1. Peserta Kegiatan Pelatihan

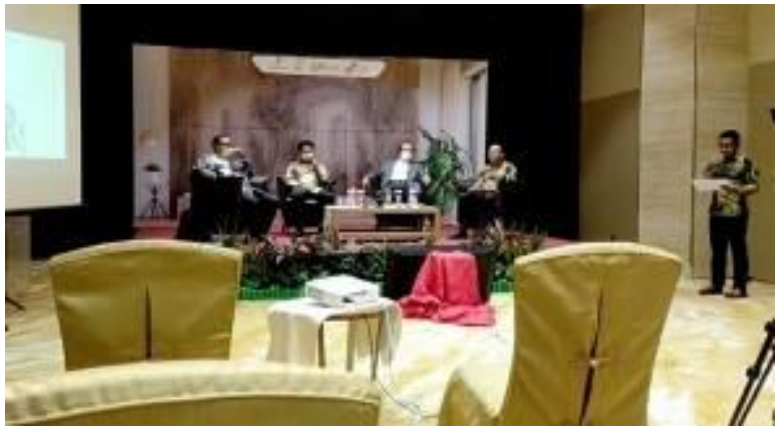

Gambar 2. Sharing Materi Kegiatan oleh Narasumber

Pada hari pertama, tim pengabdi memberikan pelatihan mengenai kepemimpinan. Pelatihan kepemimpinan ini adalah salah satu metode pengembangan sumber daya manusia yang tidak hanya mengacu pada aspek pengetahuan dasar, tetapi juga berkaitan dengan aspek keterampilan dan perilaku (Salim et al., 2018). Adapun kegiatan pelatihan kepemimpinan ini diadakan selama 1 hari dan yang menjadi objek pelatihan adalah mahasiswa. Selain ini tujuan diadakan pelatihan kepemimpinan ini adalah untuk memberikan bekal terutama kepada mahasiswa atau angkatan kerja muda dalam mempersiapkan lebih dini pada dunia kerja yang akan dihadapi. Kemudian dalam pelatihan ini target yang ingin dicapai adalah meningkatnya kemampuan dalam hal komunikasi, kerja sama tim/ individu, kemampuan bekerja di bawah tekanan, kemampuan interpersonal, motivasi kerja, serta memiliki jiwa yang berintegritas dan loyalitas.

Pada hari kedua, tim pengabdi memberikan pelatihan singkat mengenai bagaimana cara menjadi Master of Ceremony (MC) yang baik dan benar. Master of Ceremony adalah penguasa atau pemandu acara, juga berarti orang yang mengendalikan dan membawa acara, serta 
memiliki tanggung jawab dalam kelancaran suatu kegiatan (Ratna, 2017). Adapun kegiatan ini diadakan pada hari kedua setelah pelatihan kepemimpinan. Inti dari kegiatan ini adalah memberikan edukasi mengenai dasar-dasar bagaimana menjadi Master of Ceremony yang baik dan benar. Tujuan dari kegiatan ini agar mahasiswa lebih percaya diri dan memiliki keterampilan berbicara terkait jalannya suatu acara atau kegiatan.

Kemudian pada hari ketiga diadakan pelatihan desain grafis. Desain grafis merupakan suatu seni atau karya gambar dalam dua atau tiga dimensi yang mencakup kegiatan penggambaran, pelukisan, dan fotografi yang fokus pada seni atau estetika yang berlaku secara universal (Zulkarnain, 2018). Dalam kegiatan ini diajarkan kemampuan dasar dalam desain grafis seperti layouter dan editor. Dengan adanya pelatihan editor, target yang ingin dicapai adalah dapat memberikan pengetahuan kepada mahasiswa agar dapat membuat desain poster, banner, sampul yang menarik menggunakan bantuan aplikasi. Sedangkan pelatihan layouter bertujuan agar dapat memberikan pengetahuan kepada mahasiswa dalam membuat layout sebuah majalah dan media publikasi lainnya sesuai dengan tata letak agar menarik untuk dilihat.

Kemudian pada hari keempat atau hari terakhir dilakukan pelatihan jurnalistik. Jurnalistik merupakan suatu keterampilan dalam mencari, mengolah, menyusun, menyajikan, dan menyiarkan berita mengenai sebuah peristiwa yang terjadi (Hikmat, 2018). Tujuan dari pelatihan jurnalistik ini adalah memberikan pemahaman tentang pentingnya penulisan untuk tujuan jurnalistik.

Adapun target yang ingin dicapai dalam pelaksanaan kegiatan pelatihan, sebagai berikut :

1. Memberikan bekal kepada generasi muda dalam mengeksplorasi kelebihan atau bakat yang mereka miliki.

2. Meningkatkan keterampilan dan keahlian sumber daya manusia yang disesuaikan dengan atribut dan kebutuhan pasar.

3. Meningkatkan kualitas dan mendukung perencanaan sumber daya manusia.

4. Mendukung secara tidak langsung mengenai pembangunan kompetensi sumber daya manusia yang dicanangkan oleh pemerintah,

Berdasarkan kegiatan pelatihan yang telah dilakukan, secara keseluruhan progam berjalan dengan lancar dan target yang ingin dicapai dapat terlaksana dengan cukup baik. Namun ada beberapa kendala yang dihadapi, yaitu sebagai berikut :

1. Kondisi di daerah masih dalam masa pemulihan terhadap pandemik Covid-19, sehingga kegiatan masih dalam tahapan pembatasan dan tidak unstuk skala yang besar.

2. Keterbatasan waktu oleh tim pelatih, sehingga dalam pelaksanaan kegiatan dipadatkan pelaksanaannya.

3. Beberapa peserta mengalami kelelahan akibat dari dipadatkannya acara kegiatan.

Oleh karena itu, agar kendala tidak terulang lagi, maka tim pengabdi melakukan tindakan perbaikan jika kegiatan dilakukan kembali pada masa mendatang, antara lain meliputi : 
1. Jadwal acara kegiatan sebaiknya tidak dipadatkan sehingga para peserta memiliki waktu yang cukup dalam mengembangkan keterampilan.

2. Diberikan jeda / istirahat beberapa hari dari pelatihan pertama ke pelatihan selanjutnya.

3. Menggandeng lembaga yang lebih kompeten untuk mengisi acara kegiatan pelatihan.

Kemudian setelah pelaksanaan kegiatan, dilakukan evaluasi. Evaluasi kegiatan dilakukan dengan cara melakukan peninjauan terhadap tingkat kepuasan dan kemanfaatan yang dirasakan oleh para peserta terhadap pelaksanaan yang sudah dilakukan. Berdasarkan hasil evaluasi didapatkan bahwa kesadaran dan pemahaman para peserta mengenai pentingnya dalam mengembangkan keterampilan dan keahlian di masa depan meningkat dibandingkan sebelum pelaksanaan kegiatan. Oleh karena itu antara hasil evaluasi dengan pencapaian tujuan pelaksanaan kegiatan dapat tercapai dengan cukup baik.

Adapun dampak dan manfaat yang didapatkan dari kegiatan pelatihan ini adalah meningkatnya keterampilan dan keahlian peserta, meningkatkan kepercayaan diri para peserta, dan dapat membentuk karakter positif bagi para peserta. Oleh karena itu manfaat yang didapatkan oleh para peserta diharapkan dapat memberikan bekal terutama pada generasi muda untuk meningkatkan kompetensi tidak hanya keilmuan yang dipelajari di Universitas, tetapi kompetensi lain beruapa keterampilan hard skill dan soft skill yang dapat memberikan nilai tambah dan meningkatkan daya saing.

\section{SIMPULAN}

Berdasarkan hasil pelaksanaan kegiatan pelatihan hard skill dan soft skill pada $22-25$ November 2021 di Batam, dapat disimpulkan bahwa pemahaman generasi muda akan keterampilan tambahan menjadi sangat penting, hal ini karena untuk bersaing di dunia industri tidak cukup ilmu yang dipelajari dari kampus, tetapi setiap individu harus memiliki pembeda dengan lainnya, salah satu pembedanya adalah kemampuan dalam hal hard skill dan soft skill. Oleh karena itu pelaksanaan kegiatan pelatihan harus dilaksanakan pada masa mendatang supaya tercipta generasi yang unggul sesuai yang diamanatkan oleh pemerintah

\section{UCAPAN TERIMA KASIH}

Ucapan terima kasih disampaikan kepada pihak tim pelaksana kegiatan, tim narasumber, dan pihak terkait yang sudah memberikan kepercayaan kepada para tim pengabdi untuk melaksanaan kegiatan pengembangan kompetensi melalui kegiatan peningkatan hard skill dan soft skill. Harapan kedepan kerja sama ini dapat terus berlanjut dan dapat dilaksanakan kembali secara periodik.

\section{DAFTAR PUSTAKA}

Dewojati, R. K. W. (2015). Desain Grafis Sebagai Media Ungkap Periklanan. Imaji, 7(2). https://doi.org/10.21831/imaji.v7i2.6633

Hafizah, E. (2019). Implementasi tata Laksana Pedoman Master of Ceremony bagi Siswa Siswi Sekolah Dasar. Al-Hikmah, 13(1), 77. https://doi.org/10.24260/alhikmah.v13i1.1336

Hikmat, M. M. (2018). Jurnalistik Literary Journalism. In Prenadamedia Group: Vol. 
1455 Peningkatan Hard Skills dan Soft Skills pada Lingkup Organisasi - Arsyad Sumantika, Elva Susanti DOI: https://doi.org/10.31004/abdidas.v2i6.507

\section{Cetakan 1.}

Lie, N. L. C., \& Darmasetiawan, N. K. (2017). Pengaruh Soft Skill Terhadap Kesiapan Kerja Menghadapi Masyarakat Ekonomi ASEAN pada Mahasiswa S1 Fakultas Bisnis dan Ekonomika Universitas Surabaya. Jurnal Ilmiah Mahasiswa Universitas Surabaya, 6(2), https://journal.ubaya.ac.id/index.php/jimus/ar ticle/view/1074

Manara, M. U. (2014). Hard Skills Dan Soft Skills Pada Bagian Sumber Daya Manusia Di Organisasi Industri. Jurnal Psikologi Tabularasa, 9(1), 37-47.

Nur Agusta, Y. (2014). Hubungan Antara Orientasi Masa Depan dan Daya Juang terhadap Kesiapan Kerja pada Mahasiswa Tingkat Akhir Fakultas Ilmu Sosial dan Ilmu Politik di Universitas Mulawarman. Psikoborneo, 2(3), 133-140.

Ratna, Y. (2017). Public Speaking Training. Telkom Professional Certification Center, 143.

Salim, F. F., Himam, F., \& Fahmie, A. (2018). Komitmen afektif transformational leadership training to improve affective commitment. Journal of Psychological Science and Profesion (JPSP), 2(1), 93-105. http://jurnal.unpad.ac.id/jpsp/article/downloa d/16578/9944

Smeru Research Institute. (2020). Hal. 1 dari 4 (Issue 0001, pp. 3-6).

Solikin, A., Fatchurahman, H, M., \& Supardi. (2014). Anterior Jurnal,. 14, 20-28.

Zulkarnain, A. (2018). Penggunaan Desain grafis pada Majalah Hidayatullah sebagai Media Dakwah dalam Menarik Minat Baca. In Journal of Physical Therapy Science (Vol. 9, Issue 1). 